\title{
Vitamin D Supplementation in Central Nervous System Demyelinating Disease-Enough Is Enough
}

\author{
Darius Häusler ${ }^{1}$ and Martin S. Weber ${ }^{1,2, *}$ \\ 1 Institute of Neuropathology, University Medical Center, 37099 Göttingen, Germany; \\ darius.haeusler@med.uni-goettingen.de \\ 2 Department of Neurology, University Medical Center, 37099 Göttingen, Germany \\ * Correspondence: martin.weber@med.uni-goettingen.de; Tel.: +49-551-39-7706; Fax: +49-551-39-10800
}

Received: 28 September 2018; Accepted: 24 December 2018; Published: 8 January 2019

\begin{abstract}
The exact cause of multiple sclerosis (MS) remains elusive. Various factors, however, have been identified that increase an individual's risk of developing this central nervous system (CNS) demyelinating disease and are associated with an acceleration in disease severity. Besides genetic determinants, environmental factors are now established that influence MS, which is of enormous interest, as some of these contributing factors are relatively easy to change. In this regard, a low vitamin D status is associated with an elevated relapse frequency and worsened disease course in patients with MS. The most important question, however, is whether this association is causal or related. That supplementing vitamin D in MS is of direct therapeutic benefit, is still a matter of debate. In this manuscript, we first review the potentially immune modulating mechanisms of vitamin $\mathrm{D}$, followed by a summary of current and ongoing clinical trials intended to assess whether vitamin D supplementation positively influences the outcome of MS. Furthermore, we provide emerging evidence that excessive vitamin $\mathrm{D}$ treatment via the $\mathrm{T}$ cell-stimulating effect of secondary hypercalcemia, could have negative effects in CNS demyelinating disease. This jointly merges into the balancing concept of a therapeutic window of vitamin D in MS.
\end{abstract}

Keywords: multiple sclerosis; vitamin D; vitamin D receptor; experimental autoimmune encephalomyelitis; T cells; hypercalcemia

\section{Introduction}

Various factors have been discovered which determine an individual's risk of developing multiple sclerosis (MS), a chronic demyelinating disease of the central nervous system (CNS). Earlier family studies, as well as later molecular analyses, suggest a genetic predisposition for development of MS. Intriguingly, the vast majority of all genetic risk factors identified to date, encode for parts of the immune system. This supports the concept that an overwhelming (auto-)immune response leads to CNS inflammation, demyelination and neurodegeneration in the pathogenesis and progression of MS. Besides these risk genes, some environmental factors have been suggested to be involved in triggering and perpetuating MS pathogenesis [1,2]. Infections, such as a symptomatic Epstein Barr virus (EBV) at a vulnerable age [3], inhalative smoking [4] as well as lack of sun light exposure [5] and low levels of vitamin D [6] have been reported to enhance the risk of developing MS. The latter two factors could be interdependent, as the primary form of vitamin D, cholecalciferol (vitamin D3) is generated in the skin upon ultraviolet (UV) radiation. Alternatively, vitamin D can be taken up with food, such as dark fish (Figure 1). While diet is considered the minor source of vitamin D [7], it may become essential when UVB exposure is increasingly restricted, both by active prevention, as well as environmental changes [8-10]. Regardless of its relative contribution under physiological conditions, vitamin $\mathrm{D}$ levels can be effectively and rapidly raised by diet. Accordingly, the possible association 
between vitamin D and MS, and so the intuitively easy elimination of a potential MS risk factor by vitamin D supplementation has gained much interest over recent years.
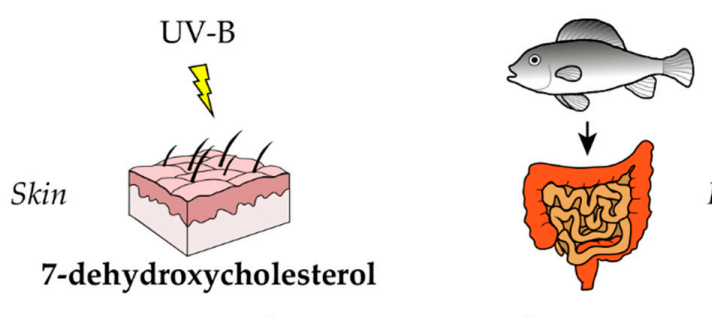

Intestine

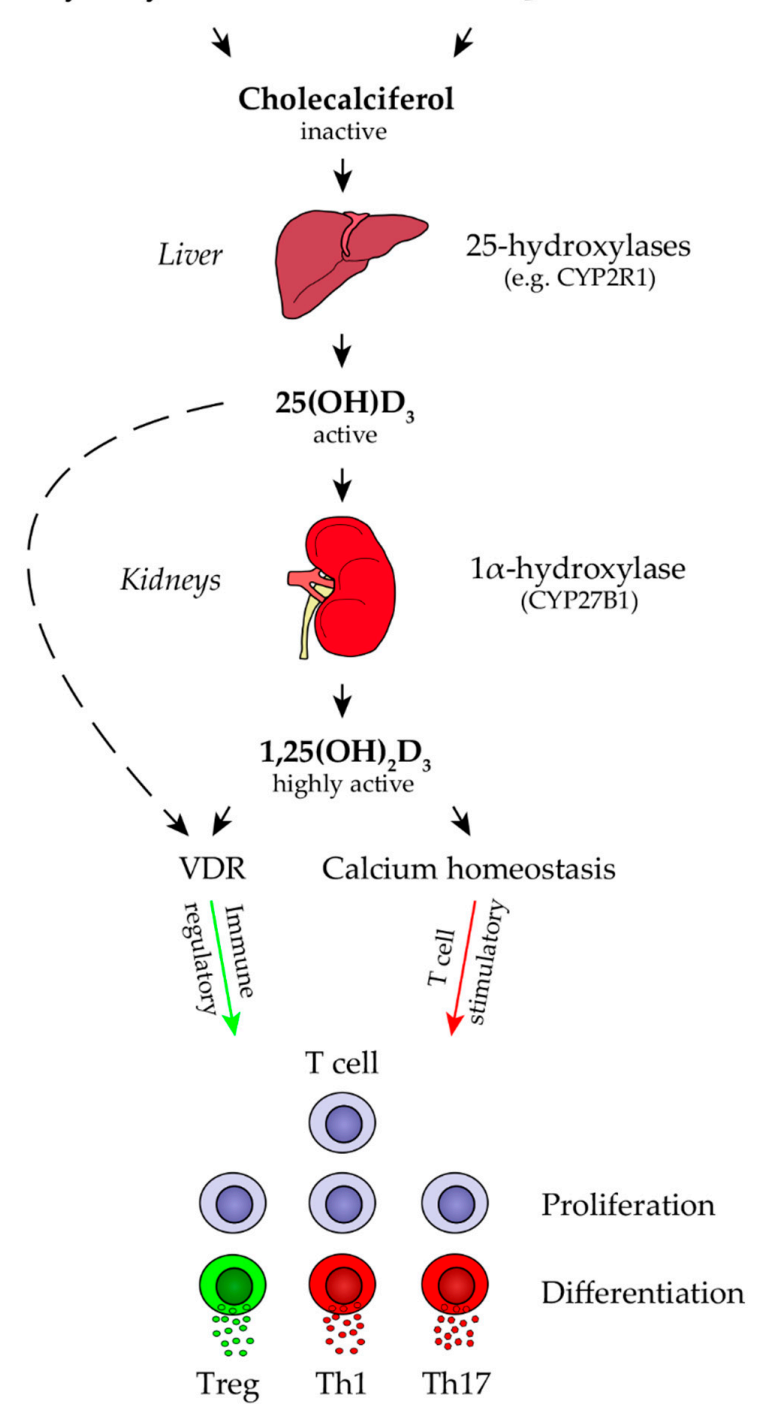

Figure 1. Vitamin D metabolism. Vitamin D (cholecalciferol) can be obtained from dietary intake or by synthesis in the skin from 7-dehydroxycholesterol in response to ultraviolet (UV) light. The first step in vitamin D metabolism occurs in the liver, where it is hydroxylated by 25-hydroxylases (CYP2R1, CYP27A1 and CYP3A4) towards 25-hydroxyvitamin D $\left(25(\mathrm{OH}) \mathrm{D}_{3}\right)$. The second step in vitamin $\mathrm{D}$ metabolism takes place mainly in the kidneys, where it is hydroxylated by $1 \alpha$-hydroxylase (CYP27B1) to the biologically most active form of vitamin $\mathrm{D}, 1,25$-dihydroxyvitamin $\mathrm{D}_{3}\left(1,25(\mathrm{OH})_{2} \mathrm{D}_{3}\right)$. Both $1,25(\mathrm{OH})_{2} \mathrm{D}_{3}$ and $25(\mathrm{OH}) \mathrm{D}_{3}$ are immune modulatory upon binding to a vitamin $\mathrm{D}$ receptor (VDR) present in the nucleus of almost all immune cells. However, $25(\mathrm{OH}) \mathrm{D}_{3}$ shows a 100 -fold less binding affinity as compared to $1,25(\mathrm{OH})_{2} \mathrm{D}_{3}$. Other functions of $1,25(\mathrm{OH})_{2} \mathrm{D}_{3}$ is the regulation of intestinal calcium and phosphate absorption, calcium mobilization from bone and reabsorption of calcium in the kidney. Secondary hypercalcemia, mediated by high serum vitamin D levels, may lead to a T cell stimulatory effect. 


\section{Vitamin D and Multiple Sclerosis}

Several aspects suggest that low levels of vitamin D could contribute to MS in a pathogenic manner. Firstly, MS patients generally have relatively low levels of vitamin D, which further decline throughout their disease course [11,12]. Most importantly, low serum levels of vitamin D are associated with an enhanced risk of developing de novo MS when analyzed in a large cohort of individuals prospectively [13]. In patients with established MS, vitamin D levels above $70 \mathrm{nmol} / \mathrm{L}$ were found to be associated with a decreased risk of attacks [14]. In contrast, lower concentrations increased the likelihood of both relapses and early chronic progression $[15,16]$. Further supporting a direct effect of vitamin D in MS, genome-wide association studies have identified that genetic abnormalities in genes encoding $1 \alpha$-hydroxylase, the rate-limiting enzyme for the conversion of vitamin $\mathrm{D}$ into its active metabolite, increased the risk of developing MS [17]. It can thus be concluded, that a higher serum level of functional vitamin D is associated with a reduced MS risk and severity. However, a causal protective effect and accordingly, whether therapeutically raising the vitamin D level alters disease severity, is a matter of ongoing debate.

\subsection{Vitamin D Metabolism and Direct Effects of Vitamin D Metabolites}

To assess a potential clinical benefit of vitamin D in MS and other autoimmune conditions, it is instrumental to recall the metabolism of this vitamin in humans. Vitamin D (cholecalciferol) is a secosteroid hormone that can be obtained from dietary intake or by synthesis in the skin from 7-dehydroxycholesterol in response to UV light (Figure 1) [18-20]. In the circulation, vitamin D binds to a specialized carrier protein, vitamin D-binding protein (DBP) and is transported to the liver, where it is hydroxylated by 25-hydroxylases (CYP2R1, CYP27A1 and CYP3A4) to 25-hydroxyvitamin $\mathrm{D}\left(25(\mathrm{OH}) \mathrm{D}_{3}\right) .25(\mathrm{OH}) \mathrm{D}_{3}$ is the most abundant metabolite in the circulation, with a half-life of 20-90 days [21,22]. Primarily based on its relative stability, measurement of this metabolite is the most accepted parameter to assess the overall vitamin $\mathrm{D}$ status in an individual patient. The second step in vitamin D metabolism takes place mainly in the kidney. Here, it is hydroxylated by $1 \alpha$-hydroxylase (CYP27B1) to the biologically most active form of vitamin D, 1,25-dihydroxyvitamin $\mathrm{D}_{3}\left(1,25(\mathrm{OH})_{2} \mathrm{D}_{3}\right)[19,23]$. The conversion into $1,25(\mathrm{OH})_{2} \mathrm{D}_{3}$ can also be performed by several immune cells, which also express CYP27B1, such as macrophages, monocytes, dendritic cells (DC), B cells and $\mathrm{T}$ cells $[24,25]$. Most biologic functions of $1,25(\mathrm{OH})_{2} \mathrm{D}_{3}$ are mediated by its strong and specific binding to a vitamin D receptor (VDR) present in the nucleus of almost all immune cells, including $\mathrm{T}$ cells [26], dendritic cells [23], monocytes and macrophages [26,27], activated B cells [25], as well as neuronal and glial cells [28-36]. $25(\mathrm{OH}) \mathrm{D}_{3}$ is also able to bind to VDR with a 100-fold less binding affinity as compared to $1,25(\mathrm{OH})_{2} \mathrm{D}_{3}$ [37]. Upon binding, a chain of genomic events is triggered, resulting in the transcriptional control of vitamin D-regulated genes [38-40]. After completion, $1,25(\mathrm{OH})_{2} \mathrm{D}_{3}$ is catabolized by repeated oxidations, converted to calcitroic acid and then excreted [37].

Most of the studies providing insight into how $1,25(\mathrm{OH})_{2} \mathrm{D}_{3}$ modulates the immune system were done in vitro. Monocytes cultured in the presence of $1,25(\mathrm{OH})_{2} \mathrm{D}_{3}$ showed a VDR-dependent loss of MHCII [41,42] and a reduction in co-stimulatory molecules, such as CD40, CD80 and CD86 [43]. This resulted in a diminished capability to induce proliferation of $\mathrm{T}$ cells upon stimulation with tetanus toxoid or CD40L [41,43]. Moreover, $1,25(\mathrm{OH})_{2} \mathrm{D}_{3}$ exposure to monocytes decreased the secretion of IL-1 $\alpha$, IL-6, IL-12, TNF- $\alpha$ and IP-10 [44-47], increased the transcription levels of IL-10 RNA [42,48] and enhanced their phagocytic function [42]. Monocytes can differentiate into immature DC in the presence of GM-CSF and IL-4 $[49,50]$ and can be further differentiated into mature DC upon TNF- $\alpha$, LPS, IL-1 or CD40L incubation in vitro [45,51,52]. Exposure to $1,25(\mathrm{OH})_{2} \mathrm{D}_{3}$ restored their monocytic phenotype [52] and inhibited DC maturation [51-54]. Furthermore, differentiated mature DCs, in the presence of $1,25(\mathrm{OH})_{2} \mathrm{D}_{3}$, showed a downregulation of CD40, CD80, CD86, as well as MHCII. They also showed a diminished release of Th1 and Th17 cell-inducing cytokines, such as IL-12 and IL-23, while the production of IL-10 and CCL22, involved in Treg and Th2 immune responses, was enhanced respectively [51-53]. In addition, co-culture of mature DC with T cells in the presence 
of $1,25(\mathrm{OH})_{2} \mathrm{D}_{3}$, resulted in less $\mathrm{T}$ cell proliferation [51,52,54]. A direct effect of $1,25(\mathrm{OH})_{2} \mathrm{D}_{3}$ on microglial cells and antigen presenting cells (APC) within the CNS, included an inhibition of TNF- $\alpha$, IL-6 and Nitric Oxide production in vitro [55]. B cells express negligible amounts of VDR and have been shown to be a target of $1,25(\mathrm{OH})_{2} \mathrm{D}_{3}$ after activation, due to their VDR up-regulation $[56,57]$. Nevertheless, exposing B cells to $1,25(\mathrm{OH})_{2} \mathrm{D}_{3}$ inhibited their proliferation $[25,58,59]$, plasma cell differentiation including immunoglobulin $\mathrm{G}$ and $-\mathrm{M}$ secretion, memory $\mathrm{B}$ cell generation and induced $B$ cell apoptosis in proliferating B cells [25]. T cell subsets show a high variability in their VDR expression levels. In contrast to high VDR levels on cytotoxic $\mathrm{CD} 8^{+} \mathrm{T}$ cells, Th2-, Th17- and Treg cells, Th1 cells exhibit moderate VDR expression, which is increased upon activation [26,60-62]. Exposing $\mathrm{T}$ cells to $1,25(\mathrm{OH})_{2} \mathrm{D}_{3}$ inhibited $\mathrm{T}$ cell proliferation, as well as Th1- and Th17-derived cytokine production, such as IL-2 [63-66], IFN- $\gamma$, IL-17, IL-21 and IL-22 [62,64,67-69]. However, it promoted the release of Th2- and Treg-derived cytokines, including IL-4, IL-5 [70] and IL-10 [71-73]. Moreover, $1,25(\mathrm{OH})_{2} \mathrm{D}_{3}$ induced cell-cycle arrest and apoptosis of activated effector $\mathrm{T}$ cells mediated by the Fas/FasL system or IL-2 [74-76]. Taken together, vitamin D and its metabolites clearly alter phenotype and function of various immune cells in vitro, and exert the vast majority of these immune modulatory properties via interaction with the VDR.

\subsection{Vitamin D Supplementation Studies in MS}

In light of this strong in vitro evidence, and the fact that a low vitamin $\mathrm{D}$ level is a negative predictor in MS, it is intuitive to study its supplementation in MS. Unfortunately, the question whether vitamin D exerts a therapeutic effect in established CNS demyelinating disease is much less clear than the in vitro evidence. In part, this is likely due to the complex interaction of vitamin D and its metabolites, not only with immune cells, but various other tissues and organs affecting regulation of multiple hormones and homeostasis of ions (Figure 1). A direct effect of vitamin D on MS activity is the requirement for all current efforts to therapeutically raise its level in affected patients. In the most widely used preclinical model of MS, murine experimental autoimmune encephalomyelitis (EAE), vitamin D indeed appeared to prevent its development [77] and to reversibly block EAE progression [78]. This effect was associated with an impaired activation and CNS migration of monocytes [79,80] and T cells [81], as well as an accentuation of anti-inflammatory natural killer T cell properties [82]. In MS patients, moderate vitamin D supplementation increased the serum level of transforming growth factor beta (TGF- $\beta$ ) [63] and reduced the frequency of Th17- and effector memory T cells [83]. Empirical vitamin D supplementation studies have so far provided conflicting results $[84,85]$, and failed to conclusively establish such causality. For example, adding vitamin $\mathrm{D}_{3}$ to interferon beta (IFN- $\beta$ ) treatment, reduced MRI activity in a small trial with relapsing-remitting MS patients [86]. In this context, a study suggested that both components interact to modulate MS disease activity. This is in the sense that, an elevated level of vitamin D is a pre-requisite for IFN- $\beta$ to properly function, and not necessarily a beneficial factor by itself [87]. Another study indicated that the initiation of IFN- $\beta$ treatment was associated with a significant reduction in all MRI outcomes, irrespective of the patients' vitamin D level. This suggests that the anti-inflammatory effect of increasing vitamin $D$ levels is small when compared to IFN- $\beta$ treatment. Moreover, it is controversial whether genetic variation in Wilms' tumor gene product 1 (WT1) plays any role in regulating the relationship between IFN- $\beta$ and serum 25-hydroxyvitamin D [88,89]. Similarly, in MS patients treated with natalizumab, supplementing vitamin $\mathrm{D}$ was reported to reduce the relapse rate when compared to its frequency prior to vitamin D supplementation [90]. Interpretation of this result, however, may be hampered by an increase in the efficacy of natalizumab itself over time [91], as the study was not controlled by a group in which vitamin D levels remained low. In the first trial examining the safety of high oral vitamin D treatment, 25 patients received escalating doses ranging from 4000 IU up to 40,000 IU per day for 28 weeks. This was followed by another 28 weeks, in which the patients were down-titrated to 4000 IU per day [92]. According to the authors, high-dose vitamin D administration was well tolerated. That being said, a follow-up study evaluating the clinical effect of high-dose vitamin D treatment in 
patients with MS, failed to show a significant clinical benefit of the high over the low-dose group [84]. In the largest interventional study thus far (SOLAR study), 229 participants were randomized to receive either daily oral cholecalciferol (14,000 IU vitamin D3) or placebo as add-on therapy to 44- $\mu \mathrm{g}$ IFN- $\beta$. Vitamin D supplementation significantly reduced the number of new MRI lesions in patients receiving IFN- $\beta$. However, the ambitious primary endpoint of the study, being a change in the proportion of patients with "no evidence of disease activity", was not formally reached $[93,94]$. Larger ongoing trials aim to determine more conclusively whether interventional vitamin D supplementation directly alters relapse frequency or accumulating disability, independent of any respective co-medication in MS $[95,96]$.

In light of these heterogeneous results thus far, alternative concepts corroborating the correlation of sunlight and MS disease activity currently arise. Exposure of the skin to sun has numerous biological effects, with UV radiation probably exerting the greatest impact. In this regard, a recent report highlights that higher actinic skin damage, as a result of UV exposure, is associated with a reduction in MS inflammatory events, independent of concomitantly raised vitamin D levels [97]. Besides promoting vitamin D synthesis, UV-B is absorbed to a large extent by urocanic acid (UCA), hereby converting from the trans-isomer to its active form cis-UCA, which conveys both cutaneous and systemic immunosuppression [98]. Cis-UCA plasma levels were found to be lower in RR-MS patients compared to healthy controls [99], this parallels vitamin D's properties [100,101]. Cis-UCA in vitro reduces the pro-inflammatory antigen presenting capacity of myeloid APCs and promotes development of Treg [99]. Enhanced Treg function and frequency is probably the most consistent immunoregulatory effect to occur upon UV irradiation. A recent study mechanistically dissected this concept in mice. UV-B light facilitated development of tolerogenic DC, which in return fostered development of EAE-ameliorating Treg [102]. Most importantly, this immune-mediated clinical effect occurred in the absence of a detectable increase in $25-(\mathrm{OH}) \mathrm{D}_{3}$ [103]. Together with the parallel observation that mice with genetically disrupted vitamin D signaling are fully susceptible to UV-mediated immunosuppression [104,105], these findings substantially question whether vitamin $\mathrm{D}$ is the central metabolite in mediating the beneficial effect of UV irradiation in CNS demyelinating disease and in explaining the association of MS with higher latitude [106].

\subsection{Possible Side Effects of Secondary Hypercalcemia}

As mentioned above and illustrated in Figure 1, vitamin D and its metabolites regulate multiple hormones and homeostasis of ions. Specifically, $1,25(\mathrm{OH})_{2} \mathrm{D}_{3}$ influences the secretion of hormones such as prolactin, parathyroid hormone (PTH), as well as insulin [37] and has complex functions in calcium and phosphorus homeostasis. The latter includes regulation of intestinal calcium and phosphate absorption, calcium mobilization from bone and reabsorption of calcium in the kidney [107]. Elevated serum $1,25(\mathrm{OH})_{2} \mathrm{D}_{3}$ in humans, hereby leads to an increased uptake of calcium from the intestines, resorption in the kidneys and may result in secondary hypercalcemia [108]. This is especially true when combined with calcium intake [109-111].

Calcium ions $\left(\mathrm{Ca}^{+}\right)$are essential second messengers in the human body and their widespread roles in biology are mirrored in the immune system [112]. Engagement of several different tyrosine and non-tyrosine kinase receptors stimulate $\mathrm{Ca}_{2}{ }^{+}$influx in immune cells, including $\mathrm{T}$ cells, $\mathrm{B}$ cells and monocytes/macrophages [113]. In T cells, antigen engagement of the $\mathrm{T}$ cell receptor triggers $\mathrm{Ca}_{2}{ }^{+}$release from intracellular stores in the endoplasmic reticulum (ER). This transient $\mathrm{Ca}_{2}{ }^{+}$release opens calcium-release activated channels (CRAC) in the plasma membrane. This, in conjunction with voltage-gated calcium channels (VGCC), results in a massive influx of extracellular $\mathrm{Ca}^{+}$into the cytosol followed by activation of calcineurin and nuclear import of NFATc proteins. These regulate immune-response genes, encoding for cell proliferation, differentiation, migration and production of cytokines [114]. Several studies suggest that extracellular calcium influx, via voltage-gated calcium channels contributes to white matter damage in acute spinal cord injury and stroke. In experimental autoimmune encephalomyelitis (EAE), the animal model of MS, administration of calcium channel 
blockers ameliorated disease [115], decreased microglial proinflammatory activity [116], fostered remyelination and induced microglia-specific apoptosis [117]. Moreover, a diminished calcium activity caused by EDTA injections showed a therapeutic effect in EAE [118]. While there is currently no molecule to selectively interfere with calcium influx into immune cells in vivo, genetically engineered $\mathrm{T}$ cells with non-functioning calcium channels completely blocked EAE by preventing development of myelin-reactive Th1 and Th17 cells $[119,120]$. In this context, we recently revisited the effect of two different doses of vitamin D in EAE [121]. We fed mice with cholecalciferol, the metabolite most commonly supplemented in humans. We measured the serum level of $25(\mathrm{OH})$ vitamin $\mathrm{D}$, which used in humans to assess the vitamin D status after several weeks. In our three dosing groups we set levels reflective of MS patients who are (a) vitamin D-deficient, (b) modestly supplemented and (c) treated in MS high dose supplementation trials [92,122]. As consistently observed in other studies, moderately substituting a low vitamin D status ameliorated EAE, which is normally associated with a dampened development and expansion of encephalitogenic T cells. In sharp contrast, we detected that supplementation with high doses of vitamin D exerted an activation of innate and adaptive immune cells, associated with enhanced CNS immune infiltration and a distinctive acceleration of EAE severity. Importantly, these mice containing vitamin D serum levels exactly mirroring the ones in humans on high dose supplementation, showed a subtle but significant rise in their mean serum calcium. Modelling these calcium levels in vitro revealed that $\mathrm{T}$ cell activation was strongly enhanced in a culture medium with higher calcium content. Importantly, this was the case when murine $\mathrm{T}$ cells were used, but even more so when human $\mathrm{T}$ cells were examined. Upon activation, an enhanced calcium influx triggered proliferation and pro-inflammatory differentiation of $\mathrm{T}$ cells. This corroborates a causal sequence of high dose vitamin D treatment, secondary hypercalcemia and a promoted development of disease-driving encephalitogenic $\mathrm{T}$ cells.

Importantly, hypercalcemia to the extent comparable to the levels associated with deterioration of EAE, commonly occurs in humans supplemented with high doses of vitamin D [108]. This is especially true when combined with calcium intake [109-111]. High dose vitamin D was also reported to cause hypercalcemia in the treatment of MS [123], which was associated with development of severely disabling relapses as well as increased MRI activity [124]. Along the same lines, recent clinical trials revealed enhanced immune cell activation in MS patients supplemented with 50,000 IU of vitamin $\mathrm{D}_{3}$ every five days [125]. Whereas the functionally opposite outcome occurred at moderate vitamin D levels $[83,94]$. In conjunction with our pre-clinical observation, these findings may indicate that the immunological and clinical benefit of vitamin $\mathrm{D}$ is reflective of immune-regulatory vitamin $\mathrm{D}$ receptor signaling. However, these desirable effects are abolished by a secondary rise in the mean calcium level when a certain dose threshold of vitamin $\mathrm{D}$ is exceeded. Therefore, we recommend a vitamin D serum level between $75-125 \mathrm{nmol} / \mathrm{L}$, as proposed by other clinicians [126]. This range of vitamin $\mathrm{D}$ has been associated with low risk of developing MS and low disease activity and can be easily reached with adequate sun exposure and vitamin D balanced diet without any additional vitamin D supplementation.

\section{Conclusions}

There is little doubt that a low vitamin D status is a risk factor for development and progression of MS. In part, this may reflect a true deficit in vitamin D itself, on the other hand, low vitamin $\mathrm{D}$ levels may be indicative of a lack of sun exposure, which appears to mediate beneficial effects independent or in addition to raising the vitamin D levels. Although, controlled supplementation studies in patients with MS suggest that therapeutically raising vitamin D in affected patients may positively influence the course of disease, conclusive evidence is unfortunately still lacking. Emerging studies caution that higher dose vitamin D supplementation may have the opposite clinical effect via secondary hypercalcemia having a $\mathrm{T}$ cell-stimulating effect. This novel concept of a relatively narrow therapeutic window for vitamin $\mathrm{D}$, may also shed light on the question of why clinical trials often using higher doses of vitamin D failed or yielded conflicting results. In conclusion, vitamin D 
should be supplemented at moderate doses in a serum level-controlled manner. Patients should be also assessed for hypercalcemia, which should be strictly avoided. In the big picture, moderate sun exposure, combined with a diverse diet including vitamin $\mathrm{D}$ precursors, in conjunction with a regular assessment of vitamin D serum levels, might be the best balanced and advisable strategy for patients with MS.

Author Contributions: D.H. wrote the manuscript and drafted the figure. M.S.W. conceptualized and wrote the manuscript.

Funding: Darius Häusler is supported by the Startprogramm of the Universitätsmedizin Göttingen. M.S. Weber is serving as an editor for PLoS One. He receives research support from the Deutsche Forschungsgemeinschaft (DFG; WE 3547/5-1), from Novartis, TEVA, Biogen-Idec, Roche, Merck and the ProFutura Programm of the Universitätsmedizin Göttingen.

Conflicts of Interest: The authors declare no conflict of interest.

\section{References}

1. Ascherio, A.; Munger, K.L. Environmental risk factors for multiple sclerosis. Part I: The role of infection. Ann. Neurol. 2007, 61, 288-299. [CrossRef] [PubMed]

2. Ascherio, A.; Munger, K.L. Environmental risk factors for multiple sclerosis. Part II: Noninfectious factors. Ann. Neurol. 2007, 61, 504-513. [CrossRef] [PubMed]

3. Ascherio, A.; Munger, K.L. Epstein-barr virus infection and multiple sclerosis: A review. J. Neuroimmune Pharmacol. 2010, 5, 271-277. [CrossRef] [PubMed]

4. Wingerchuk, D.M. Smoking: Effects on multiple sclerosis susceptibility and disease progression. Ther. Adv. Neurol. Disord. 2012, 5, 13-22. [CrossRef] [PubMed]

5. Bjornevik, K.; Riise, T.; Casetta, I.; Drulovic, J.; Granieri, E.; Holmoy, T.; Kampman, M.T.; Landtblom, A.M.; Lauer, K.; Lossius, A.; et al. Sun exposure and multiple sclerosis risk in Norway and Italy: The EnvIMS study. Mult. Scler. 2014, 20, 1042-1049. [CrossRef] [PubMed]

6. Ascherio, A.; Munger, K.L.; Simon, K.C. Vitamin D and multiple sclerosis. Lancet Neurol. 2010, 9, 599-612. [CrossRef]

7. Holick, M.F. Sunlight and vitamin D for bone health and prevention of autoimmune diseases, cancers, and cardiovascular disease. Am. J. Clin. Nutr. 2004, 80, 1678S-1688S. [CrossRef]

8. Holick, M.F. Biological Effects of Sunlight, Ultraviolet Radiation, Visible Light, Infrared Radiation and Vitamin D for Health. Anticancer Res. 2016, 36, 1345-1356. [PubMed]

9. Holick, M.F. Environmental factors that influence the cutaneous production of vitamin D. Am. J. Clin. Nutr. 1995, 61, 638S-645S. [CrossRef]

10. Holick, M.F. Photosynthesis of vitamin D in the skin: Effect of environmental and life-style variables. Fed. Proc. 1987, 46, 1876-1882.

11. Van der Mei, I.A.; Ponsonby, A.L.; Dwyer, T.; Blizzard, L.; Taylor, B.V.; Kilpatrick, T.; Butzkueven, H.; McMichael, A.J. Vitamin D levels in people with multiple sclerosis and community controls in Tasmania, Australia. J. Neurol. 2007, 254, 581-590.

12. Nieves, J.; Cosman, F.; Herbert, J.; Shen, V.; Lindsay, R. High prevalence of vitamin D deficiency and reduced bone mass in multiple sclerosis. Neurology 1994, 44, 1687-1692. [CrossRef] [PubMed]

13. Munger, K.L.; Levin, L.I.; Hollis, B.W.; Howard, N.S.; Ascherio, A. Serum 25-hydroxyvitamin D levels and risk of multiple sclerosis. JAMA 2006, 296, 2832-2838. [CrossRef] [PubMed]

14. Smolders, J.; Menheere, P.; Kessels, A.; Damoiseaux, J.; Hupperts, R. Association of vitamin D metabolite levels with relapse rate and disability in multiple sclerosis. Mult. Scler. 2008, 14, 1220-1224. [CrossRef] [PubMed]

15. Runia, T.F.; Hop, W.C.; de Rijke, Y.B.; Buljevac, D.; Hintzen, R.Q. Lower serum vitamin D levels are associated with a higher relapse risk in multiple sclerosis. Neurology 2012, 79, 261-266. [CrossRef]

16. Mowry, E.M.; Krupp, L.B.; Milazzo, M.; Chabas, D.; Strober, J.B.; Belman, A.L.; McDonald, J.C.; Oksenberg, J.R.; Bacchetti, P.; Waubant, E. Vitamin D status is associated with relapse rate in pediatric-onset multiple sclerosis. Ann. Neurol. 2010, 67, 618-624. 
17. The International Multiple Sclerosis Genetics Consortium; The Wellcome Trust Case Control Consortium; Sawcer, S.; Hellenthal, G.; Pirinen, M.; Spencer, C.C.; Patsopoulos, N.A.; Moutsianas, L.; Dilthey, A.; $\mathrm{Su}, \mathrm{Z}$; ; et al. Genetic risk and a primary role for cell-mediated immune mechanisms in multiple sclerosis. Nature 2011, 476, 214-219. [CrossRef]

18. DeLuca, H.F. Overview of general physiologic features and functions of vitamin D. Am. J. Clin. Nutr. 2004, 80, 1689S-1696S. [CrossRef]

19. Holick, M.F. The vitamin D epidemic and its health consequences. J. Nutr. 2005, 135, 2739S-2748S. [CrossRef]

20. Tavera-Mendoza, L.E.; White, J.H. Cell defenses and the sunshine vitamin. Sci. Am. 2007, 297, 62-65, 68-70, 72. [CrossRef]

21. Mawer, E.B.; Lumb, G.A.; Stanbury, S.W. Long biological half-life of vitamin D3 and its polar metabolites in human serum. Nature 1969, 222, 482-483. [CrossRef] [PubMed]

22. Smith, J.E.; Goodman, D.S. The turnover and transport of vitamin D and of a polar metabolite with the properties of 25-hydroxycholecalciferol in human plasma. J. Clin. Investig. 1971, 50, 2159-2167. [CrossRef] [PubMed]

23. Hewison, M. Vitamin D and immune function: Autocrine, paracrine or endocrine? Scand. J. Clin. Lab. Investig. Suppl. 2012, 243, 92-102.

24. Overbergh, L.; Decallonne, B.; Valckx, D.; Verstuyf, A.; Depovere, J.; Laureys, J.; Rutgeerts, O.; Saint-Arnaud, R.; Bouillon, R.; Mathieu, C. Identification and immune regulation of 25-hydroxyvitamin D-1-alpha-hydroxylase in murine macrophages. Clin. Exp. Immunol. 2000, 120, 139-146. [CrossRef] [PubMed]

25. Chen, S.; Sims, G.P.; Chen, X.X.; Gu, Y.Y.; Chen, S.; Lipsky, P.E. Modulatory effects of 1,25-dihydroxyvitamin D3 on human B cell differentiation. J. Immunol. 2007, 179, 1634-1647. [CrossRef]

26. Veldman, C.M.; Cantorna, M.T.; DeLuca, H.F. Expression of 1,25-dihydroxyvitamin D(3) receptor in the immune system. Arch. Biochem. Biophys. 2000, 374, 334-338. [CrossRef] [PubMed]

27. Bhalla, A.K.; Amento, E.P.; Clemens, T.L.; Holick, M.F.; Krane, S.M. Specific high-affinity receptors for 1,25-dihydroxyvitamin D3 in human peripheral blood mononuclear cells: Presence in monocytes and induction in T lymphocytes following activation. J. Clin. Endocrinol. Metab. 1983, 57, 1308-1310. [CrossRef]

28. Clemens, T.L.; Garrett, K.P.; Zhou, X.Y.; Pike, J.W.; Haussler, M.R.; Dempster, D.W. Immunocytochemical localization of the 1,25-dihydroxyvitamin D3 receptor in target cells. Endocrinology 1988, 122, 1224-1230. [CrossRef] [PubMed]

29. Sutherland, M.K.; Somerville, M.J.; Yoong, L.K.; Bergeron, C.; Haussler, M.R.; McLachlan, D.R. Reduction of vitamin D hormone receptor mRNA levels in Alzheimer as compared to Huntington hippocampus: Correlation with calbindin-28k mRNA levels. Brain Res. Mol. Brain Res. 1992, 13, 239-250. [CrossRef]

30. Neveu, I.; Naveilhan, P.; Jehan, F.; Baudet, C.; Wion, D.; De Luca, H.F.; Brachet, P. 1,25-dihydroxyvitamin D3 regulates the synthesis of nerve growth factor in primary cultures of glial cells. Brain Res. Mol. Brain Res. 1994, 24, 70-76. [CrossRef]

31. Johnson, J.A.; Grande, J.P.; Windebank, A.J.; Kumar, R. 1,25-Dihydroxyvitamin D(3) receptors in developing dorsal root ganglia of fetal rats. Brain Res. Dev. Brain Res. 1996, 92, 120-124. [CrossRef]

32. Veenstra, T.D.; Prufer, K.; Koenigsberger, C.; Brimijoin, S.W.; Grande, J.P.; Kumar, R. 1,25-Dihydroxyvitamin D3 receptors in the central nervous system of the rat embryo. Brain Res. 1998, 804, 193-205. [CrossRef]

33. Cornet, A.; Baudet, C.; Neveu, I.; Baron-Van Evercooren, A.; Brachet, P.; Naveilhan, P. 1,25-Dihydroxyvitamin D3 regulates the expression of VDR and NGF gene in Schwann cells in vitro. J. Neurosci. Res. 1998, 53, 742-746. [CrossRef]

34. Prufer, K.; Veenstra, T.D.; Jirikowski, G.F.; Kumar, R. Distribution of 1,25-dihydroxyvitamin D3 receptor immunoreactivity in the rat brain and spinal cord. J. Chem. Neuroanat. 1999, 16, 135-145. [CrossRef]

35. Baas, D.; Prufer, K.; Ittel, M.E.; Kuchler-Bopp, S.; Labourdette, G.; Sarlieve, L.L.; Brachet, P. Rat oligodendrocytes express the vitamin $\mathrm{D}(3)$ receptor and respond to 1,25-dihydroxyvitamin $\mathrm{D}(3)$. Glia 2000, 31, 59-68. [CrossRef]

36. Langub, M.C.; Herman, J.P.; Malluche, H.H.; Koszewski, N.J. Evidence of functional vitamin D receptors in rat hippocampus. Neuroscience 2001, 104, 49-56. [CrossRef]

37. Holick, M.F. Vitamin D, 1st ed.; Springer Science+Business Media: New York, NY, USA, 1999; Volume XII, 458p.

38. Darwish, H.; DeLuca, H.F. Vitamin D-regulated gene expression. Crit. Rev. Eukaryot. Gene Expr. 1993, 3, 89-116. [PubMed] 
39. Haussler, M.R.; Haussler, C.A.; Jurutka, P.W.; Thompson, P.D.; Hsieh, J.C.; Remus, L.S.; Selznick, S.H.; Whitfield, G.K. The vitamin D hormone and its nuclear receptor: Molecular actions and disease states. J. Endocrinol. 1997, 154 (Suppl. 3), S57-S73.

40. Haussler, M.R.; Whitfield, G.K.; Haussler, C.A.; Hsieh, J.C.; Thompson, P.D.; Selznick, S.H.; Dominguez, C.E.; Jurutka, P.W. The nuclear vitamin D receptor: Biological and molecular regulatory properties revealed. J. Bone Miner. Res. 1998, 13, 325-349. [CrossRef]

41. Rigby, W.F.; Waugh, M.; Graziano, R.F. Regulation of human monocyte HLA-DR and CD4 antigen expression, and antigen presentation by 1,25-dihydroxyvitamin D3. Blood 1990, 76, 189-197.

42. Xu, H.; Soruri, A.; Gieseler, R.K.; Peters, J.H. 1,25-Dihydroxyvitamin D3 exerts opposing effects to IL-4 on MHC class-II antigen expression, accessory activity, and phagocytosis of human monocytes. Scand. J. Immunol. 1993, 38, 535-540. [CrossRef] [PubMed]

43. Almerighi, C.; Sinistro, A.; Cavazza, A.; Ciaprini, C.; Rocchi, G.; Bergamini, A. 1Alpha,25-dihydroxyvitamin D3 inhibits CD40L-induced pro-inflammatory and immunomodulatory activity in human monocytes. Cytokine 2009, 45, 190-197. [CrossRef] [PubMed]

44. D’Ambrosio, D.; Cippitelli, M.; Cocciolo, M.G.; Mazzeo, D.; Di Lucia, P.; Lang, R.; Sinigaglia, F.; Panina-Bordignon, P. Inhibition of IL-12 production by 1,25-dihydroxyvitamin D3. Involvement of NF-kappaB downregulation in transcriptional repression of the p40 gene. J. Clin. Investig. 1998, 101, 252-262. [CrossRef] [PubMed]

45. Jonuleit, H.; Kuhn, U.; Muller, G.; Steinbrink, K.; Paragnik, L.; Schmitt, E.; Knop, J.; Enk, A.H. Pro-inflammatory cytokines and prostaglandins induce maturation of potent immunostimulatory dendritic cells under fetal calf serum-free conditions. Eur. J. Immunol. 1997, 27, 3135-3142. [CrossRef] [PubMed]

46. Zarrabeitia, M.T.; Riancho, J.A.; Amado, J.A.; Olmos, J.M.; Gonzalez-Macias, J. Effect of calcitriol on the secretion of prostaglandin E2, interleukin 1, and tumor necrosis factor alpha by human monocytes. Bone 1992, 13, 185-189. [CrossRef]

47. Kuo, Y.T.; Kuo, C.H.; Lam, K.P.; Chu, Y.T.; Wang, W.L.; Huang, C.H.; Hung, C.H. Effects of vitamin D3 on expression of tumor necrosis factor-alpha and chemokines by monocytes. J. Food Sci. 2010, 75, H200-H204. [CrossRef]

48. Matilainen, J.M.; Husso, T.; Toropainen, S.; Seuter, S.; Turunen, M.P.; Gynther, P.; Yla-Herttuala, S.; Carlberg, C.; Vaisanen, S. Primary effect of 1alpha,25(OH)(2)D(3) on IL-10 expression in monocytes is short-term down-regulation. Biochim. Biophys. Acta 2010, 1803, 1276-1286. [CrossRef] [PubMed]

49. Romani, N.; Gruner, S.; Brang, D.; Kampgen, E.; Lenz, A.; Trockenbacher, B.; Konwalinka, G.; Fritsch, P.O.; Steinman, R.M.; Schuler, G. Proliferating dendritic cell progenitors in human blood. J. Exp. Med. 1994, 180, 83-93. [CrossRef] [PubMed]

50. Chapuis, F.; Rosenzwajg, M.; Yagello, M.; Ekman, M.; Biberfeld, P.; Gluckman, J.C. Differentiation of human dendritic cells from monocytes in vitro. Eur. J. Immunol. 1997, 27, 431-441. [CrossRef]

51. Penna, G.; Adorini, L. 1 Alpha,25-dihydroxyvitamin D3 inhibits differentiation, maturation, activation, and survival of dendritic cells leading to impaired alloreactive T cell activation. J. Immunol. 2000, 164, 2405-2411. [CrossRef]

52. Piemonti, L.; Monti, P.; Sironi, M.; Fraticelli, P.; Leone, B.E.; Dal Cin, E.; Allavena, P.; Di Carlo, V. Vitamin D3 affects differentiation, maturation, and function of human monocyte-derived dendritic cells. J. Immunol. 2000, 164, 4443-4451. [CrossRef] [PubMed]

53. Van Halteren, A.G.; van Etten, E.; de Jong, E.C.; Bouillon, R.; Roep, B.O.; Mathieu, C. Redirection of human autoreactive T-cells Upon interaction with dendritic cells modulated by TX527, an analog of 1,25 dihydroxyvitamin D(3). Diabetes 2002, 51, 2119-2125. [CrossRef] [PubMed]

54. Griffin, M.D.; Lutz, W.; Phan, V.A.; Bachman, L.A.; McKean, D.J.; Kumar, R. Dendritic cell modulation by 1alpha,25 dihydroxyvitamin D3 and its analogs: A vitamin D receptor-dependent pathway that promotes a persistent state of immaturity in vitro and in vivo. Proc. Natl. Acad. Sci. USA 2001, 98, 6800-6805. [CrossRef] [PubMed]

55. Lefebvre d'Hellencourt, C.; Montero-Menei, C.N.; Bernard, R.; Couez, D. Vitamin D3 inhibits proinflammatory cytokines and nitric oxide production by the EOC13 microglial cell line. J. Neurosci. Res. 2003, 71, 575-582. [CrossRef] [PubMed]

56. Provvedini, D.M.; Tsoukas, C.D.; Deftos, L.J.; Manolagas, S.C. 1,25-dihydroxyvitamin D3 receptors in human leukocytes. Science 1983, 221, 1181-1183. [CrossRef] 
57. Provvedini, D.M.; Tsoukas, C.D.; Deftos, L.J.; Manolagas, S.C. 1 alpha,25-Dihydroxyvitamin D3-binding macromolecules in human B lymphocytes: Effects on immunoglobulin production. J. Immunol. 1986, 136, 2734-2740. [PubMed]

58. Iho, S.; Takahashi, T.; Kura, F.; Sugiyama, H.; Hoshino, T. The effect of 1,25-dihydroxyvitamin D3 on in vitro immunoglobulin production in human B cells. J. Immunol. 1986, 136, 4427-4431. [PubMed]

59. Lemire, J.M.; Adams, J.S.; Sakai, R.; Jordan, S.C. 1 alpha,25-dihydroxyvitamin D3 suppresses proliferation and immunoglobulin production by normal human peripheral blood mononuclear cells. J. Clin. Investig. 1984, 74, 657-661. [CrossRef]

60. Nashold, F.E.; Hoag, K.A.; Goverman, J.; Hayes, C.E. Rag-1-dependent cells are necessary for 1,25-dihydroxyvitamin $\mathrm{D}(3)$ prevention of experimental autoimmune encephalomyelitis. J. Neuroimmunol. 2001, 119, 16-29. [CrossRef]

61. Palmer, M.T.; Lee, Y.K.; Maynard, C.L.; Oliver, J.R.; Bikle, D.D.; Jetten, A.M.; Weaver, C.T. Lineage-specific effects of 1,25-dihydroxyvitamin D(3) on the development of effector CD4 T cells. J. Biol. Chem. 2011, 286, 997-1004. [CrossRef]

62. Chang, S.H.; Chung, Y.; Dong, C. Vitamin D suppresses Th17 cytokine production by inducing C/EBP homologous protein (CHOP) expression. J. Biol. Chem. 2010, 285, 38751-38755. [CrossRef] [PubMed]

63. Mahon, B.D.; Gordon, S.A.; Cruz, J.; Cosman, F.; Cantorna, M.T. Cytokine profile in patients with multiple sclerosis following vitamin D supplementation. J. Neuroimmunol. 2003, 134, 128-132. [CrossRef]

64. Jeffery, L.E.; Burke, F.; Mura, M.; Zheng, Y.; Qureshi, O.S.; Hewison, M.; Walker, L.S.; Lammas, D.A.; Raza, K.; Sansom, D.M. 1,25-Dihydroxyvitamin D3 and IL-2 combine to inhibit T cell production of inflammatory cytokines and promote development of regulatory T cells expressing CTLA-4 and FoxP3. J. Immunol. 2009, 183, 5458-5467. [CrossRef] [PubMed]

65. Thien, R.; Baier, K.; Pietschmann, P.; Peterlik, M.; Willheim, M. Interactions of 1 alpha,25-dihydroxyvitamin D3 with IL-12 and IL-4 on cytokine expression of human T lymphocytes. J. Allergy Clin. Immunol. 2005, 116, 683-689. [CrossRef] [PubMed]

66. Willheim, M.; Thien, R.; Schrattbauer, K.; Bajna, E.; Holub, M.; Gruber, R.; Baier, K.; Pietschmann, P.; Reinisch, W.; Scheiner, O.; et al. Regulatory effects of 1alpha,25-dihydroxyvitamin D3 on the cytokine production of human peripheral blood lymphocytes. J. Clin. Endocrinol. Metab. 1999, 84, 3739-3744. [PubMed]

67. Bartels, L.E.; Jorgensen, S.P.; Agnholt, J.; Kelsen, J.; Hvas, C.L.; Dahlerup, J.F. 1,25-dihydroxyvitamin D3 and dexamethasone increase interleukin-10 production in CD4+ T cells from patients with Crohn's disease. Int. Immunopharmacol. 2007, 7, 1755-1764. [CrossRef] [PubMed]

68. Ikeda, U.; Wakita, D.; Ohkuri, T.; Chamoto, K.; Kitamura, H.; Iwakura, Y.; Nishimura, T. 1alpha,25-Dihydroxyvitamin D3 and all-trans retinoic acid synergistically inhibit the differentiation and expansion of Th17 cells. Immunol. Lett. 2010, 134, 7-16. [CrossRef]

69. Colin, E.M.; Asmawidjaja, P.S.; van Hamburg, J.P.; Mus, A.M.; van Driel, M.; Hazes, J.M.; van Leeuwen, J.P.; Lubberts, E. 1,25-dihydroxyvitamin D3 modulates Th17 polarization and interleukin-22 expression by memory $\mathrm{T}$ cells from patients with early rheumatoid arthritis. Arthritis Rheumatol. 2010, 62, $132-142$. [CrossRef]

70. Boonstra, A.; Barrat, F.J.; Crain, C.; Heath, V.L.; Savelkoul, H.F.; O'Garra, A. 1alpha,25-Dihydroxyvitamin $\mathrm{d} 3$ has a direct effect on naive CD4(+) T cells to enhance the development of Th2 cells. J. Immunol. 2001, 167, 4974-4980. [CrossRef]

71. Khoo, A.L.; Joosten, I.; Michels, M.; Woestenenk, R.; Preijers, F.; He, X.H.; Netea, M.G.; van der Ven, A.J.; Koenen, H.J. 1,25-Dihydroxyvitamin D3 inhibits proliferation but not the suppressive function of regulatory $\mathrm{T}$ cells in the absence of antigen-presenting cells. Immunology 2011, 134, 459-468. [CrossRef]

72. Van Belle, T.L.; Vanherwegen, A.S.; Feyaerts, D.; De Clercq, P.; Verstuyf, A.; Korf, H.; Gysemans, C.; Mathieu, C. 1,25-Dihydroxyvitamin D3 and its analog TX527 promote a stable regulatory T cell phenotype in T cells from type 1 diabetes patients. PLOS ONE 2014, 9, e109194. [CrossRef] [PubMed]

73. Urry, Z.; Chambers, E.S.; Xystrakis, E.; Dimeloe, S.; Richards, D.F.; Gabrysova, L.; Christensen, J.; Gupta, A.; Saglani, S.; Bush, A.; et al. The role of 1alpha,25-dihydroxyvitamin D3 and cytokines in the promotion of distinct Foxp3+ and IL-10+ CD4+ T cells. Eur. J. Immunol. 2012, 42, 2697-2708. [CrossRef] [PubMed]

74. Cippitelli, M.; Fionda, C.; Di Bona, D.; Di Rosa, F.; Lupo, A.; Piccoli, M.; Frati, L.; Santoni, A. Negative regulation of CD95 ligand gene expression by vitamin D3 in T lymphocytes. J. Immunol. 2002, 168, 1154-1166. [CrossRef] [PubMed] 
75. Decallonne, B.; van Etten, E.; Overbergh, L.; Valckx, D.; Bouillon, R.; Mathieu, C. 1Alpha,25-dihydroxyvitamin D3 restores thymocyte apoptosis sensitivity in non-obese diabetic (NOD) mice through dendritic cells. J. Autoimmun. 2005, 24, 281-289. [CrossRef] [PubMed]

76. Pintado, C.O.; Carracedo, J.; Rodriguez, M.; Perez-Calderon, R.; Ramirez, R. 1 alpha, 25-dihydroxyvitamin D3 (calcitriol) induces apoptosis in stimulated T cells through an IL-2 dependent mechanism. Cytokine 1996, 8, 342-345. [CrossRef] [PubMed]

77. Lemire, J.M.; Archer, D.C. 1,25-dihydroxyvitamin D3 prevents the in vivo induction of murine experimental autoimmune encephalomyelitis. J. Clin. Investig. 1991, 87, 1103-1107. [CrossRef] [PubMed]

78. Cantorna, M.T.; Hayes, C.E.; DeLuca, H.F. 1,25-Dihydroxyvitamin D3 reversibly blocks the progression of relapsing encephalomyelitis, a model of multiple sclerosis. Proc. Natl. Acad. Sci. USA 1996, 93, 7861-7864. [CrossRef]

79. Pedersen, L.B.; Nashold, F.E.; Spach, K.M.; Hayes, C.E. 1,25-dihydroxyvitamin D3 reverses experimental autoimmune encephalomyelitis by inhibiting chemokine synthesis and monocyte trafficking. J. Neurosci. Res. 2007, 85, 2480-2490. [CrossRef]

80. Nashold, F.E.; Miller, D.J.; Hayes, C.E. 1,25-dihydroxyvitamin D3 treatment decreases macrophage accumulation in the CNS of mice with experimental autoimmune encephalomyelitis. J. Neuroimmunol. 2000, 103, 171-179. [CrossRef]

81. Mayne, C.G.; Spanier, J.A.; Relland, L.M.; Williams, C.B.; Hayes, C.E. 1,25-Dihydroxyvitamin D3 acts directly on the $\mathrm{T}$ lymphocyte vitamin $\mathrm{D}$ receptor to inhibit experimental autoimmune encephalomyelitis. Eur. J. Immunol. 2011, 41, 822-832. [CrossRef]

82. Waddell, A.; Zhao, J.; Cantorna, M.T. NKT cells can help mediate the protective effects of 1,25-dihydroxyvitamin D3 in experimental autoimmune encephalomyelitis in mice. Int. Immunol. 2015, 27, 237-244. [CrossRef]

83. Sotirchos, E.S.; Bhargava, P.; Eckstein, C.; Van Haren, K.; Baynes, M.; Ntranos, A.; Gocke, A.; Steinman, L.; Mowry, E.M.; Calabresi, P.A. Safety and immunologic effects of high- vs. low-dose cholecalciferol in multiple sclerosis. Neurology 2016, 86, 382-390. [CrossRef] [PubMed]

84. Stein, M.S.; Liu, Y.; Gray, O.M.; Baker, J.E.; Kolbe, S.C.; Ditchfield, M.R.; Egan, G.F.; Mitchell, P.J.; Harrison, L.C.; Butzkueven, H.; et al. A randomized trial of high-dose vitamin D2 in relapsing-remitting multiple sclerosis. Neurology 2011, 77, 1611-1618. [CrossRef] [PubMed]

85. Loken-Amsrud, K.I.; Holmoy, T.; Bakke, S.J.; Beiske, A.G.; Bjerve, K.S.; Bjornara, B.T.; Hovdal, H.; Lilleas, F.; Midgard, R.; Pedersen, T.; et al. Vitamin D and disease activity in multiple sclerosis before and during interferon-beta treatment. Neurology 2012, 79, 267-273. [CrossRef] [PubMed]

86. Soilu-Hanninen, M.; Aivo, J.; Lindstrom, B.M.; Elovaara, I.; Sumelahti, M.L.; Farkkila, M.; Tienari, P.; Atula, S.; Sarasoja, T.; Herrala, L.; et al. A randomised, double blind, placebo controlled trial with vitamin D3 as an add on treatment to interferon beta- $1 \mathrm{~b}$ in patients with multiple sclerosis. J. Neurol. Neurosurg. Psychiatry 2012, 83, 565-571. [CrossRef] [PubMed]

87. Stewart, N.; Simpson, S., Jr.; van der Mei, I.; Ponsonby, A.L.; Blizzard, L.; Dwyer, T.; Pittas, F.; Eyles, D.; Ko, P.; Taylor, B.V. Interferon-beta and serum 25-hydroxyvitamin D interact to modulate relapse risk in MS. Neurology 2012, 79, 254-260. [CrossRef]

88. Lin, R.; Taylor, B.V.; Charlesworth, J.; van der Mei, I.; Blizzard, L.; Stewart, N.; Ponsonby, A.L.; Dwyer, T.; Pittas, F.; Simpson, S., Jr. Modulating effects of WT1 on interferon-beta-vitamin D association in MS. Acta Neurol. Scand. 2015, 131, 231-239. [CrossRef]

89. Holmoy, T.; Esbensen, Q.Y.; Torkildsen, O.; Wergeland, S.; Bjerve, K.S.; Beiske, A.G.; Midgard, R.; Saltyte-Benth, J.; Hovdal, H.; Myhr, K.M. WT1 and interferon-beta-vitamin D association in MS: A longitudinal study. Acta Neurol. Scand. 2016, 133, 309-312. [CrossRef]

90. Laursen, J.H.; Sondergaard, H.B.; Sorensen, P.S.; Sellebjerg, F.; Oturai, A.B. Vitamin D supplementation reduces relapse rate in relapsing-remitting multiple sclerosis patients treated with natalizumab. Mult. Scler. Relat. Disord. 2016, 10, 169-173. [CrossRef]

91. Cobo-Calvo, A.; Bau, L.; Matas, E.; Romero-Pinel, L.; Mane Martinez, M.A.; Majos, C.; Martinez Yelamos, S. Effectiveness of natalizumab in patients with highly active relapsing remitting multiple sclerosis. Eur. Neurol. 2015, 73, 220-229. [CrossRef]

92. Burton, J.M.; Kimball, S.; Vieth, R.; Bar-Or, A.; Dosch, H.M.; Cheung, R.; Gagne, D.; D'Souza, C.; Ursell, M.; O'Connor, P. A phase I/II dose-escalation trial of vitamin D3 and calcium in multiple sclerosis. Neurology 2010, 74, 1852-1859. [CrossRef] [PubMed] 
93. Available online: https:// onlinelibrary.ectrims-congress.eu/ectrims/2016/32nd/147013/raymond.hupperts. high.dose.cholecalciferol.28vitamin.d329.oil.as.add-on.therapy.html (accessed on 29 December 2018).

94. Muris, A.H.; Smolders, J.; Rolf, L.; Thewissen, M.; Hupperts, R.; Damoiseaux, J.; SOLARIUM Study Group. Immune regulatory effects of high dose vitamin D3 supplementation in a randomized controlled trial in relapsing remitting multiple sclerosis patients receiving IFNbeta; the SOLARIUM study. J. Neuroimmunol. 2016, 300, 47-56. [CrossRef] [PubMed]

95. Bhargava, P.; Cassard, S.; Steele, S.U.; Azevedo, C.; Pelletier, D.; Sugar, E.A.; Waubant, E.; Mowry, E.M. The vitamin D to ameliorate multiple sclerosis (VIDAMS) trial: Study design for a multicenter, randomized, double-blind controlled trial of vitamin D in multiple sclerosis. Contemp. Clin. Trials 2014, 39, 288-293. [CrossRef]

96. Dorr, J.; Ohlraun, S.; Skarabis, H.; Paul, F. Efficacy of vitamin D supplementation in multiple sclerosis (EVIDIMS Trial): Study protocol for a randomized controlled trial. Trials 2012, 13, 15. [CrossRef] [PubMed]

97. Lucas, R.M.; Ponsonby, A.L.; Dear, K.; Valery, P.C.; Pender, M.P.; Taylor, B.V.; Kilpatrick, T.J.; Dwyer, T.; Coulthard, A.; Chapman, C.; et al. Sun exposure and vitamin D are independent risk factors for CNS demyelination. Neurology 2011, 76, 540-548. [CrossRef] [PubMed]

98. Gibbs, N.K.; Tye, J.; Norval, M. Recent advances in urocanic acid photochemistry, photobiology and photoimmunology. Photochem. Photobiol. Sci. 2008, 7, 655-667. [CrossRef]

99. Correale, J.; Farez, M.F. Modulation of multiple sclerosis by sunlight exposure: Role of cis-urocanic acid. J. Neuroimmunol. 2013, 261, 134-140. [CrossRef]

100. Correale, J.; Ysrraelit, M.C.; Gaitan, M.I. Immunomodulatory effects of Vitamin D in multiple sclerosis. Brain 2009, 132, 1146-1160. [CrossRef]

101. Smolders, J.; Thewissen, M.; Peelen, E.; Menheere, P.; Tervaert, J.W.; Damoiseaux, J.; Hupperts, R. Vitamin D status is positively correlated with regulatory $\mathrm{T}$ cell function in patients with multiple sclerosis. PLoS ONE 2009, 4, e6635. [CrossRef]

102. Breuer, J.; Schwab, N.; Schneider-Hohendorf, T.; Marziniak, M.; Mohan, H.; Bhatia, U.; Gross, C.C.; Clausen, B.E.; Weishaupt, C.; Luger, T.A.; et al. Ultraviolet B light attenuates the systemic immune response in central nervous system autoimmunity. Ann. Neurol. 2014, 75, 739-758. [CrossRef]

103. Becklund, B.R.; Severson, K.S.; Vang, S.V.; DeLuca, H.F. UV radiation suppresses experimental autoimmune encephalomyelitis independent of vitamin D production. Proc. Natl. Acad. Sci. USA 2010, 107, 6418-6423. [CrossRef] [PubMed]

104. Schwarz, A.; Navid, F.; Sparwasser, T.; Clausen, B.E.; Schwarz, T. 1,25-dihydroxyvitamin D exerts similar immunosuppressive effects as UVR but is dispensable for local UVR-induced immunosuppression. J. Investig. Dermatol. 2012, 132, 2762-2769. [CrossRef] [PubMed]

105. Wang, Y.; Marling, S.J.; Martino, V.M.; Prahl, J.M.; Deluca, H.F. The absence of 25-hydroxyvitamin D3-1alphahydroxylase potentiates the suppression of EAE in mice by ultraviolet light. J. Steroid Biochem. Mol. Biol. 2016, 163, 98-102. [CrossRef]

106. Tao, C.; Simpson, S., Jr.; van der Mei, I.; Blizzard, L.; Havrdova, E.; Horakova, D.; Shaygannejad, V.; Lugaresi, A.; Izquierdo, G.; Trojano, M.; et al. Higher latitude is significantly associated with an earlier age of disease onset in multiple sclerosis. J. Neurol. Neurosurg. Psychiatry 2016, 87, 1343-1349. [CrossRef] [PubMed]

107. Barragan, M.; Good, M.; Kolls, J.K. Regulation of Dendritic Cell Function by Vitamin D. Nutrients 2015, 7, 8127-8151. [CrossRef] [PubMed]

108. Malihi, Z.; Wu, Z.; Stewart, A.W.; Lawes, C.M.; Scragg, R. Hypercalcemia, hypercalciuria, and kidney stones in long-term studies of vitamin D supplementation: A systematic review and meta-analysis. Am. J. Clin. Nutr. 2016, 104, 1039-1051. [CrossRef] [PubMed]

109. Jansen, T.L.; Janssen, M.; de Jong, A.J. Severe hypercalcaemia syndrome with daily low-dose vitamin D supplementation. Br. J. Rheumatol. 1997, 36, 712-713. [CrossRef]

110. Avenell, A.; Mak, J.C.; O'Connell, D. Vitamin D and vitamin D analogues for preventing fractures in post-menopausal women and older men. Cochrane Database Syst. Rev. 2014, CD000227. [CrossRef]

111. Bjelakovic, G.; Gluud, L.L.; Nikolova, D.; Whitfield, K.; Wetterslev, J.; Simonetti, R.G.; Bjelakovic, M.; Gluud, C. Vitamin D supplementation for prevention of mortality in adults. Cochrane Database Syst. Rev. 2014, CD007470. [CrossRef]

112. Vig, M.; Kinet, J.P. Calcium signaling in immune cells. Nat. Immunol. 2009, 10, 21-27. [CrossRef] 
113. Radermacher, A.N.; Crabtree, G.R. Monster protein controls calcium entry and fights infection. Immunity 2008, 28, 13-14. [CrossRef] [PubMed]

114. Lodygin, D.; Flugel, A. Intravital real-time analysis of T-cell activation in health and disease. Cell Calcium 2017, 64, 118-129. [CrossRef] [PubMed]

115. Brand-Schieber, E.; Werner, P. Calcium channel blockers ameliorate disease in a mouse model of multiple sclerosis. Exp. Neurol. 2004, 189, 5-9. [CrossRef] [PubMed]

116. Espinosa-Parrilla, J.F.; Martinez-Moreno, M.; Gasull, X.; Mahy, N.; Rodriguez, M.J. The L-type voltage-gated calcium channel modulates microglial pro-inflammatory activity. Mol. Cell. Neurosci. 2015, 64, 104-115. [CrossRef] [PubMed]

117. Schampel, A.; Volovitch, O.; Koeniger, T.; Scholz, C.J.; Jorg, S.; Linker, R.A.; Wischmeyer, E.; Wunsch, M.; Hell, J.W.; Ergun, S.; et al. Nimodipine fosters remyelination in a mouse model of multiple sclerosis and induces microglia-specific apoptosis. Proc. Natl. Acad. Sci. USA 2017, 114, E3295-E3304. [CrossRef] [PubMed]

118. Mosayebi, G.; Haghmorad, D.; Namaki, S.; Ghazavi, A.; Ekhtiari, P.; Mirshafiey, A. Therapeutic effect of EDTA in experimental model of multiple sclerosis. Immunopharmacol. Immunotoxicol. 2010, 32, 321-326. [CrossRef] [PubMed]

119. Ma, J.; McCarl, C.A.; Khalil, S.; Luthy, K.; Feske, S. T-cell-specific deletion of STIM1 and STIM2 protects mice from EAE by impairing the effector functions of Th1 and Th17 cells. Eur. J. Immunol. 2010, 40, 3028-3042. [CrossRef]

120. Schuhmann, M.K.; Stegner, D.; Berna-Erro, A.; Bittner, S.; Braun, A.; Kleinschnitz, C.; Stoll, G.; Wiendl, H.; Meuth, S.G.; Nieswandt, B. Stromal interaction molecules 1 and 2 are key regulators of autoreactive T cell activation in murine autoimmune central nervous system inflammation. J. Immunol. 2010, 184, 1536-1542. [CrossRef]

121. Häusler, D.; Torke, S.; Peelen, E.; Bertsch, T.; Djukic, M.; Nau, R.; Larochelle, C.; Zamvil, S.S.; Brück, W.; Weber, M.S. Continuous high dose vitamin D exacerbates central nervous system autoimmune disease by raising T cell excitatory calcium. Brain, in revision.

122. Smolders, J.; Peelen, E.; Thewissen, M.; Cohen Tervaert, J.W.; Menheere, P.; Hupperts, R.; Damoiseaux, J. Safety and T cell modulating effects of high dose vitamin D3 supplementation in multiple sclerosis. PLoS ONE 2010, 5, e15235. [CrossRef]

123. Marcus, J.F.; Shalev, S.M.; Harris, C.A.; Goodin, D.S.; Josephson, S.A. Severe hypercalcemia following vitamin d supplementation in a patient with multiple sclerosis: A note of caution. Arch. Neurol. 2012, 69, 129-132. [CrossRef] [PubMed]

124. Fragoso, Y.D.; Adoni, T.; Damasceno, A.; de Albuquerque Damasceno, C.A.; Ferreira, M.L.; Finkelzstejn, A.; Gomes, S.; Goncalves, M.V.; Grzesiuk, A.K.; Lins, S.; et al. Unfavorable outcomes during treatment of multiple sclerosis with high doses of vitamin D. J. Neurol. Sci. 2014, 346, 341-342. [CrossRef] [PubMed]

125. Naghavi Gargari, B.; Behmanesh, M.; Shirvani Farsani, Z.; Pahlevan Kakhki, M.; Azimi, A.R. Vitamin D supplementation up-regulates IL-6 and IL-17A gene expression in multiple sclerosis patients. Int. Immunopharmacol. 2015, 28, 414-419. [CrossRef] [PubMed]

126. Holmoy, T.; Kampman, M.T.; Smolders, J. Vitamin D in multiple sclerosis: Implications for assessment and treatment. Expert Rev. Neurother. 2012, 12, 1101-1112. [CrossRef] [PubMed]

(C) 2019 by the authors. Licensee MDPI, Basel, Switzerland. This article is an open access article distributed under the terms and conditions of the Creative Commons Attribution (CC BY) license (http://creativecommons.org/licenses/by/4.0/). 